\title{
A critical analysis of diet in seventeen deep sea fishes along the South-eastern Arabian Sea
}

\author{
V. VIJI, K. C. HARISH, ALPHI KORATH AND M. S. SILEESH \\ Kerala University of Fisheries and Ocean Studies, Panangad, Kochi - 682 506, Kerala, India \\ e-mail: akorath@gmail.com
}

\begin{abstract}
Diet analysis of 1190 fishes belonging to 17 species of deep sea fishes were conducted. The samples were collected from the South-eastern Arabian Sea in bottom trawl by the research vessel FORV Sagar Sampada (cruise no. 322 and 345) during January 2014 and October 2015, between lat. 7- $15^{\circ} \mathrm{N}$ and long. $78-72^{\circ} \mathrm{E}$ in the depth range $200-1000 \mathrm{~m}$. Diet composition, feeding strength, size range, depth range, distribution and index of preponderance were ascertained for all the species. It was observed that the deep sea fishes mainly feed on benthic and epibenthic organisms such as fishes, shrimps, crabs and squids, revealing their carnivorous nature. Deep sea shrimps are one of the major diet components of these fishes, which is an indication of the availability of good quantity of deep sea shrimps, along the South-eastern Arabian Sea and this abundant population can be commercially utilised in order to lessen the pressure of overexploitation being experienced in case of coastal shrimps.
\end{abstract}

Keywords: Carnivorous, Diet composition, Feeding intensity, Overexploitation

\section{Introduction}

Diet is one of the fundamental needs of an organism. It is also recognised as the key factor regulating the development, abundance and migration pattern of fishes. Fish feeding and food habits have been related to productivity of marine ecosystem, which is resolute by physical and chemical factors (Judith et al., 2002). Food and feeding are two important parameters in an ecological food web. Assessing the type of food and mode of feeding of an organism will help us to derive information on the trophic level to which the organism belongs. Diet and feeding habits of fishes also give information for understanding the trophic interactions, prey-predator relationships in aquatic food webs, the structure of marine communities and for developing ecosystem models (Garvey et al., 1998; Vander Zanden et al., 2000, Bachok, et al., 2004; Modica et al., 2014).

The abundance of prey population is very fewer in deeper waters compared to the shallow and coastal areas (Venu and Kurup, 2006). Distribution and richness of any fish species is greatly influenced by prey availability and its potentiality in the region. Diet composition of deep sea fishes was resolute to recognise its food and prey preference. Index of preponderance (Natarajan and Jhingran, 1962) and the index of relative importance (Pinkas, 1971) have been extensively used for analysis of stomach contents of fish, as these give a perfect and perceptible basis for grading the different food items and also to give a collective depiction of frequency of occurrence as well as volume respectively.

In the present study, stomach contents of 1190 deep sea fishes belonging to 17 species were examined. The diet composition, feeding intensity, size range, depth range, distribution and index of preponderance were analysed for all the species.

\section{Materials and methods}

Samples were collected during FORV Sagar Sampada cruise survey (cruise no. 322 and 345) during January 2014 and October 2015 (lat. $7^{0}-15^{\circ} \mathrm{N}$ and long. $78^{\circ}-72^{\circ} \mathrm{E}$ ). R 'marmap'(R Core Team, 2016) was used for plotting the stations (Fig. 1). Surveys were conducted during day time using HSDT-CV (High Speed Demersal TrawlCrustacean Version) and HOT (High Opening Trawl) nets in 23 stations, at 200 to $1000 \mathrm{~m}$ depth along the south-east of Arabian Sea. Total catch and number of each species of fish collected were recorded. The samples were sorted into groups and species level identification was done as per Smith and Heemstra (1986). Total length of the fishes were measured. Sex identification was done by macroscopic examination of the gonads. For food and feeding studies, the stomachs were dissected out and the contents were cautiously detached and examined. The fullness of stomach was measured based on the relative distension of stomach by visual inspection and graded as full or stuffed, $3 / 4$ full, $1 / 2$ full, $1 /{ }_{4}$ full, trace and empty (Kurup and Samuel, 1986). 


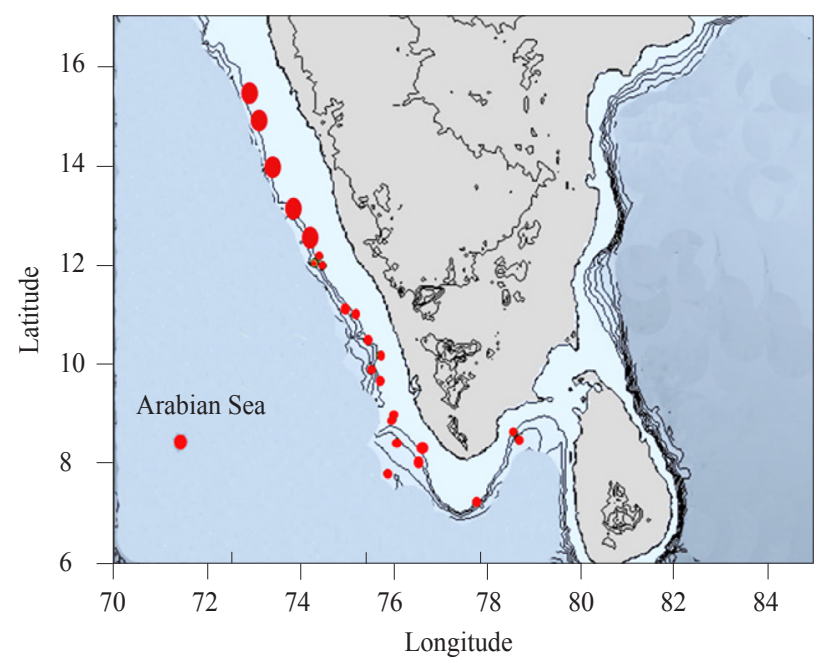

Fig. 1. Map showing the study area

Stomach content analysis was done by visual/microscopic examination. The diet components were identified as far as possible up to species, genus or family level, depending upon the status of the food and the extent of digestion (Smith and Heemstra, 1986). If the digestion had proceeded to an advanced stage and the prey were mixed with large quantity of mucus making identification difficult, it was treated as digested matter.

For grading of stomach contents, index of preponderance (Natarajan and Jhingran, 1961) was used. The index of preponderance is determined using the formula:

$\mathrm{I}=\mathrm{ViOi} / \mathrm{\Sigma ViOi} \times 100$,

where ' $\mathrm{Vi}$ ' is the percentage volume and ' $\mathrm{Oi}$ ' is the percentage of occurrence of a particular food item.

\section{Results and discussions}

The stomach contents of 1190 fishes belonging to 15 families and 17 species were analysed. Fishes of different size groups were taken for the analysis (Table 1).

The diet components of all species comprised semi-digested fishes, semi-digested shrimps, crabs and digested matter. Majority of the fishes analysed for gut contents were found to have empty stomach and the proportion of empty stomachs varied widely among the species. The feeding intensity recorded for the deep sea fishes are detailed in Fig. 2. Empty stomachs were observed to be $83 \%$ in Psenopsis cyanea. Higher proportion of empty stomach were also observed in Neoepinnula orientalis (77\%), Satyrichthys laticeps (65\%), Cubiceps baxteri (64\%), Alepocephalus bicolor (61\%) and Bembrops caudimacula (51\%). Many large predators feed infrequently and all are found with empty stomachs (Gartner et al., 1997). The frequent occurrence of empty stomachs may be attributed to faster digestion due to strong gastric juice in carnivorous fishes (Qasim, 1972). Diet characteristics of fish populations for which empty stomachs were frequent may be quite different than those for which empty stomachs were rare (Steven and Garvey, 2006). Higher proportion of full stomach condition was found in Chlorophthalmus agassizi (52\%), Priacanthus hamrur (46\%) and Uranoscopus crassiceps (46\%). Lowest proportion of stomach fullness was found in $N$. orientalis $(4 \%), C$. baxteri $(5 \%)$ and P. scyanea $(5 \%)$. Higher proportion of half fullness was found in Bathyuroconger vicinus (62\%), Bathyclupea hoskynii (52\%) and P. hamrur (39\%).

Table 1. List of species selected for diet analysis

\begin{tabular}{|c|c|c|c|c|}
\hline Family name & Species name & Sample size & Length range $(\mathrm{cm})$ & Depth (m) \\
\hline Centrolophidae & Psenopsis cyanea (Alcock, 1890) & 217 & $13.7-17.1$ & 200 \\
\hline Gempylidae & Neoepinnula orientalis (Gilchrist \& von Bonde, 1924) & 91 & $15.0-25.3$ & 200 \\
\hline Percophidae & Bembrops caudimacula (Steindachner, 1876) & 148 & $16.5-20.5$ & 200 \\
\hline Nomeidae & Cubiceps baxteri (McCulloch, 1923) & 197 & $13.2-17.2$ & 300 \\
\hline Bathyclupeidae & Bathyclupea hoskynii (Alcock,1891) & 40 & $13.5-19.0$ & 350 \\
\hline Peristediidae & Satyrichthys laticeps (Schlegel, 1848) & 89 & $17.9-39.6$ & 200 \\
\hline Triglidae & Pterygotrigla hemisticta (Temminck \& Schlegel, 1843) & 58 & $11.6-17.5$ & 200 \\
\hline Chlorophthalmidae & Chlorophthalmus agassizi (Bonaparte, 1840) & 44 & $15.8-17.1$ & 300 \\
\hline Bothidae & Chascanopsetta lugubris (Alcock, 1894) & 39 & $13.4-21.8$ & 300 \\
\hline Alepocephalidae & Alepocephalus bicolor (Alcock, 1891) & 38 & $31.4-44.0$ & 1000 \\
\hline Alepocephalidae & Rouleina attrita (Vaillant, 1888) & 35 & $15.2-22.5$ & 1000 \\
\hline Congridae & Bathyuroconger vicinus (Vaillant, 1888) & 13 & $60.0-72.3$ & 1000 \\
\hline Priacanthidae & Priacanthus hamrur (Forsskal, 1775) & 28 & $13.8-16.3$ & 300 \\
\hline Chlorophthalmidae & Chlorophthalmus corniger (Alcock, 1894) & 58 & $11.3-14.8$ & 300 \\
\hline Proscylliidae & Eridacnis radcliffei (Smith,1913) & 23 & $8.50-14.5$ & 350 \\
\hline Bythitidae & Hephthocara simum (Alcock, 1892) & 33 & $14.5-21.5$ & 1000 \\
\hline Uranoscopidae & Uranoscopus crassiceps (Alcock, 1890) & 39 & $12.6-19.8$ & 200 \\
\hline
\end{tabular}




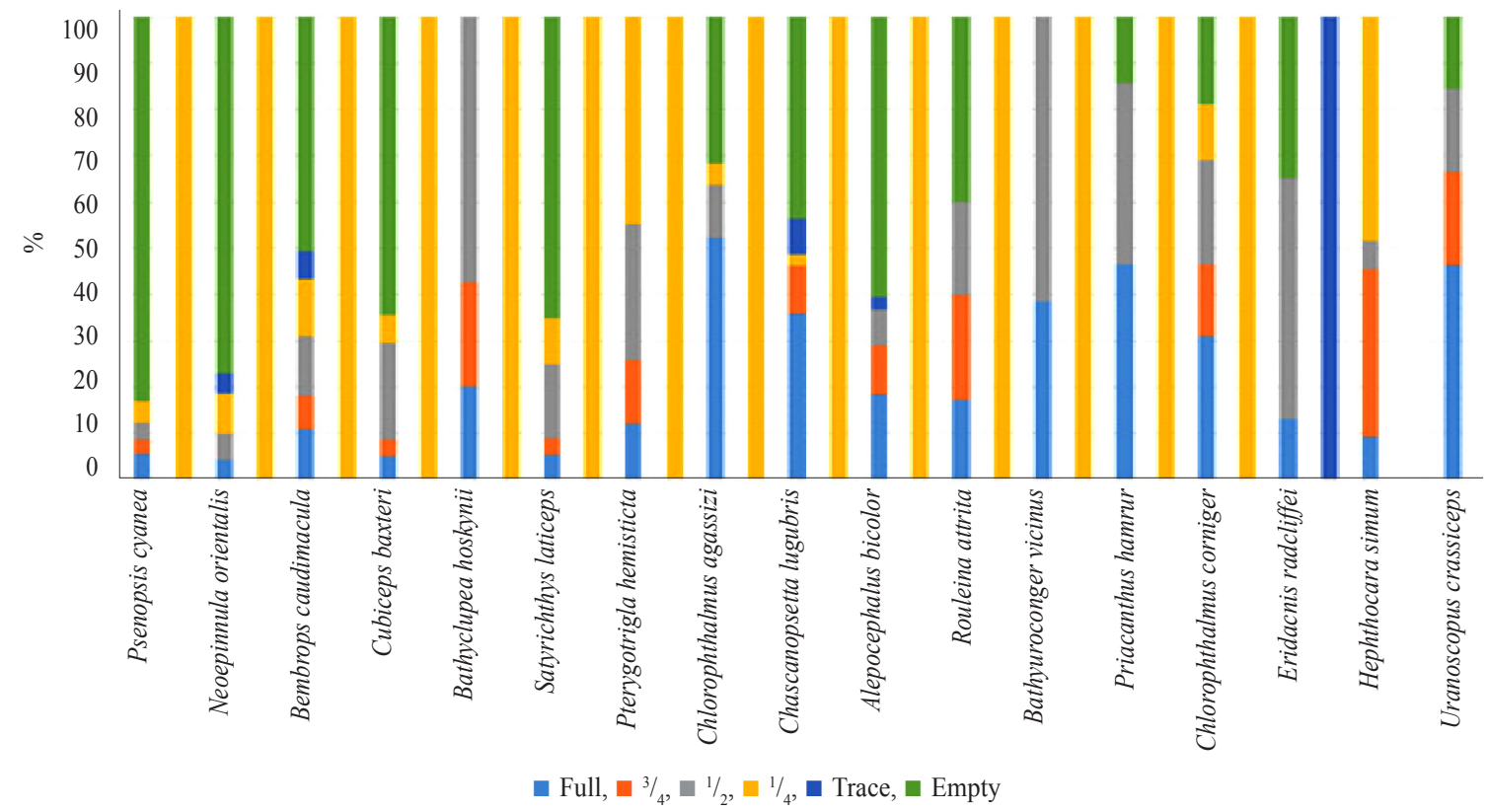

Fig. 2. Feeding intensity recorded for deep sea fishes

Shrimps and fishes were the major components of diet observed in the stomach of $P$. cyanea and traces of plankton were also observed in some specimens. In $N$. orientalis the diet comprised of shrimps and Trichiurus spp. Karuppasamy et al. (2008) reported that, myctophids and shrimps were the dominant food items in $N$. orientalis. In $C$. baxteri, squid, digested matter, shrimps, crab, eel and fish scales were found in the stomach. Diet composition of each species are detailed in Table 2. Squids and shrimps were observed in the stomach of B. hoskynii. In B. viscinus and C. corniger, the stomach contents were observed in digested condition and the diet components could not be identified. Shrimps, squids and small sized Saurida spp. were observed from the stomach of $P$. hamrur. According to Karuppasamy et al. (2008), C. corniger, C. agassizi and P. hamrur mainly fed on shrimps along with fishes and other organisms. Shrimps comprised mostly juveniles of Aristeus sp., Heterocarpus sp., Plesionika sp. and the fishes included myctophids, Platycephalus sp., Synogrops sp. and Leptocephalus larvae. In the present study, no difference was observed between the diet of both males and females of each species. Concerning diet composition, a relatively low contribution of squid was found in the diet of the deep sea fishes.

Most of the fishes collected from different depth zones showed a similar pattern of prey exploitation. Shrimp was the most important component in the diet of almost all species examined. The feeding intensity may be linked mostly to the availability of prey species. The diet preference of predatory fishes is very complex
Table 2. Diet composition of deep sea fishes

\begin{tabular}{|c|c|}
\hline Species & Diet composition \\
\hline Psenopsis cyanea & $\begin{array}{l}\text { Digested matter, shrimps (Aristeus } \\
\text { sp., Heterocarpussp.), fishes, plankton }\end{array}$ \\
\hline Neoepinnula orientalis & $\begin{array}{l}\text { Digested matter, shrimps, } \\
\text { Trichiurus sp. }\end{array}$ \\
\hline Bembrops caudimacula & $\begin{array}{l}\text { Digested matter, Synogrops sp., } \\
\text { Plesionica sp., squid }\end{array}$ \\
\hline Cubiceps baxteri & $\begin{array}{l}\text { Squid, digested matter, shrimps, crab, } \\
\text { eel, fish scales }\end{array}$ \\
\hline Bathyclupea hoskynii & Squid and shrimps \\
\hline Satyrichthys laticeps & $\begin{array}{l}\text { Shrimps, Platycephalus sp., } \\
\text { digested matter }\end{array}$ \\
\hline Pterygotrigla hemisticta & Shrimp, crab, Acetes sp. \\
\hline Chlorophthalmus agassizi & $\begin{array}{l}\text { Shrimps, Myctophids and } \\
\text { digested matter }\end{array}$ \\
\hline Chascanopsetta lugubris & Fishes and digested matter \\
\hline Alepocephalus bicolor & Digested matter and fish scales \\
\hline Rouleinaattrita & Shrimps and digested matter \\
\hline Bathyuroconger vicinus & Digested matter \\
\hline Priacanthus hamrur & Shrimps, squids and Saurida sp. \\
\hline Chlorophthalmus corniger & Digested matter \\
\hline Eridacnis radcliffei & Fish, crustaceans and fish scales \\
\hline Hephthocara simum & $\begin{array}{l}\text { Digested matter, partially digested } \\
\text { crustacean parts }\end{array}$ \\
\hline Uranoscopus crassiceps & $\begin{array}{l}\text { Digested matter, Platycephalus sp., } \\
\text { eel and shrimps }\end{array}$ \\
\hline
\end{tabular}

and is influenced by many factors such as prey availability as well as mobility, richness, prey energy content, size selection and seasonal changes (Nieland,1980; Hart and Ison, 1991; Barry and Ehret, 1993). Myctophids, Aristeus alckocki, Heterocarpus sp., squids and digested 
prey items were dominant in the diet components of deep sea fishes studied and no planktonic organisms were observed except in P. cyanea. In general, the feeding strategy observed is that, deep sea fishes consume relatively small sized organisms as prey, which are available at the time of their feeding. During the analysis, a very few quantity of plankton were observed in stomachs of a few specimens of $P$. cyanea. This may be an indication of the vertical migration behaviour exhibited by this species.
More studies have to be conducted to ascertain this behaviour.

Index of preponderance (I) was worked out for 14 species, and is presented in Table 3. It provides a definite and assessable basis for grading the various food items as it gives a combined picture of frequency of occurrence as well as volume. The index of preponderance of $P$. cyanea showed that crustaceans $(I=94.5)$ ranked first and plankton the last. Fishes

Table 3. Index of preponderance of 14 deep sea fishes

\begin{tabular}{|c|c|c|c|}
\hline Species & Diet composition & Index of preponderance (I) & Grading \\
\hline Psenopsis cyanea & $\begin{array}{l}\text { Crustaceans } \\
\text { Digested matter } \\
\text { Fishes } \\
\text { Plankton }\end{array}$ & $\begin{array}{l}94.5 \\
3.6 \\
1.7 \\
0.2\end{array}$ & $\begin{array}{l}\text { I } \\
\text { II } \\
\text { III } \\
\text { IV }\end{array}$ \\
\hline Neoepinnula orientalis & $\begin{array}{l}\text { Fishes } \\
\text { Digested matter }\end{array}$ & $\begin{array}{l}99.81 \\
0.19\end{array}$ & $\begin{array}{l}\text { I } \\
\text { II }\end{array}$ \\
\hline Bembrops caudimacula & $\begin{array}{l}\text { Crustaceans } \\
\text { Fishes } \\
\text { Digested matter } \\
\text { Squid }\end{array}$ & $\begin{array}{l}44.87 \\
38.22 \\
16.86 \\
0.05\end{array}$ & $\begin{array}{l}\text { I } \\
\text { II } \\
\text { III } \\
\text { IV }\end{array}$ \\
\hline Cubiceps baxteri & $\begin{array}{l}\text { Squid } \\
\text { Fishes } \\
\text { Crustaceans }\end{array}$ & $\begin{array}{l}92.6 \\
7.1 \\
0.16\end{array}$ & $\begin{array}{l}\text { I } \\
\text { II } \\
\text { III }\end{array}$ \\
\hline Bathyclupea hoskynii & $\begin{array}{l}\text { Crustaceans } \\
\text { Squids } \\
\text { Digested matter }\end{array}$ & $\begin{array}{l}99.47 \\
0.42 \\
0.11\end{array}$ & $\begin{array}{l}\text { I } \\
\text { II } \\
\text { III }\end{array}$ \\
\hline Satyrichthys laticeps & $\begin{array}{l}\text { Fishes } \\
\text { Crustaceans } \\
\text { Digested matter }\end{array}$ & $\begin{array}{l}83.4 \\
12.1 \\
4.5\end{array}$ & $\begin{array}{l}\text { I } \\
\text { II } \\
\text { III }\end{array}$ \\
\hline Pterygotrigla hemisticta & $\begin{array}{l}\text { Crustaceans } \\
\text { Digested matter }\end{array}$ & $\begin{array}{l}99.6 \\
0.4\end{array}$ & $\begin{array}{l}\text { I } \\
\text { II }\end{array}$ \\
\hline Chlorophthalmus agassizi & $\begin{array}{l}\text { Crustaceans } \\
\text { Fishes } \\
\text { Digested matter }\end{array}$ & $\begin{array}{l}81.55 \\
18.26 \\
0.19\end{array}$ & $\begin{array}{l}\text { I } \\
\text { II } \\
\text { III }\end{array}$ \\
\hline Chascanopsetta lugubris & $\begin{array}{l}\text { Digested matter } \\
\text { Fishes }\end{array}$ & $\begin{array}{l}93.41 \\
6.59\end{array}$ & $\begin{array}{l}\text { I } \\
\text { II }\end{array}$ \\
\hline Rouleina attrita & $\begin{array}{l}\text { Crustaceans } \\
\text { Digested matter }\end{array}$ & $\begin{array}{l}86.1 \\
13.9\end{array}$ & $\begin{array}{l}\text { I } \\
\text { II }\end{array}$ \\
\hline Priacanthus hamrur & $\begin{array}{l}\text { Crustaceans } \\
\text { Fishes } \\
\text { Squids } \\
\text { Digested matter }\end{array}$ & $\begin{array}{l}75.8 \\
20 \\
3.5 \\
0.67\end{array}$ & $\begin{array}{l}\text { I } \\
\text { II } \\
\text { III } \\
\text { IV }\end{array}$ \\
\hline Eridacnis radcliffei & $\begin{array}{l}\text { Fishes } \\
\text { Digested matter } \\
\text { Crustaceans }\end{array}$ & $\begin{array}{l}92 \\
7 \\
1\end{array}$ & $\begin{array}{l}\text { I } \\
\text { II } \\
\text { III }\end{array}$ \\
\hline Hephthocara simum & $\begin{array}{l}\text { Crustaceans } \\
\text { Digested matter }\end{array}$ & $\begin{array}{l}76.52 \\
23.48\end{array}$ & $\begin{array}{l}\text { I } \\
\text { II }\end{array}$ \\
\hline Uranoscopus crassiceps & $\begin{array}{l}\text { Fishes } \\
\text { Digested matter } \\
\text { Crustaceans }\end{array}$ & $\begin{array}{l}63.6 \\
29 \\
7.4\end{array}$ & $\begin{array}{l}\text { I } \\
\text { II } \\
\text { III }\end{array}$ \\
\hline
\end{tabular}


ranked first in the prey groups of $N$. orientalis followed by digested matter as second. Similarly, in S. laticeps also fishes $(\mathrm{I}=83.4)$ topped in the gut content followed by crustaceans and digested matter. Squid ( $\mathrm{I}=92.6$ ) dominated the diet in $C$. baxteri followed by fishes and crustaceans. In Chascanopsetta lugubris, digested matter ranked first $(\mathrm{I}=93.4)$ in the gut contents followed by fishes. In P. hamrur and Hephthocara simum, crustaceans ranked first among the prey items. In B. hoskynii, $P$. hamrur and B. caudimacula, squid was also found and ranked second, third and fourth positions respectively.

In the present study, we perceived that the deep sea fishes mainly feed on benthic and epibenthic organisms such as fishes, shrimps, crabs and squids. Similar prey exploitation was observed in different groups. The deep sea shrimps are one of the major diet components of these fishes, which is also an indication of the availability of good quantity of deep sea shrimps along the South-eastern Arabian Sea, which can be commercially utilised in order to lessen the burden on coastal shrimps.

\section{Acknowledgements}

The authors are grateful for the encouragement given by KUFOS, Panangad, Kochi. The financial assistance received from the CMLRE, MoES, Govt. of India for this work carried out under the project "Biology, Resource characteristics and stock assessment of deep sea finfishes and prawns in the depth of 200 -1200 m along the Southern and Central Indian Ocean" is gratefully acknowledged. We would also like to thank the cruise team of FORV Sagar Sampada.

\section{References}

Bachok, Z., Mansor, M. I. and Noordin, R. M. 2004. Diet composition and food habits of demersal and pelagic marine fishes from Terengganu waters, east coast of Peninsular Malaysia. NAGA, World Fish Center Quart., 27: 41-47.

Barry, J. P. and Ehret, M. J. 1993. Diet, food preference and algal availability for fishes and crabs on intertidal reef communities in southern California. Environ. Biol. Fish., 37: 75-95.

Gartner, J. V. Jr., Carbtree, R. and Sulak, K. J. 1997. Feeding at depth. In: Randall, D. J. and Farrell, A. P. (Eds.), Deep-sea fishes, Academic Press, p. 115-193.

Garvey, E., Dingledine, N. A., Donovan, N. S. and Stein, R. A. 1998. Exploring spatial and temporal variation within reservoir food webs: predictions for fish assemblages. Ecol. Applic., 8: 104-120.
Hart, P. J. B. and Ison, S. 1991. The influence of prey size and abundance and individual phenotypeon prey choice by the three-spined stickleback, Gasterosteus aculeatus L. J. Fish Biol., 38: 359-372.

Judith, A. Nyunja, Kenneth, M. Mavuti and Enock O. Wakwabi 2002. Trophic ecology of Sardinella gibbosa (Pisces: Clupeidae) and Atherinomorous lacunosus (Pisces: Atherinidae) in Mtwapa Creek and Wasini Channel, Kenya, Western Indian Ocean J. Mar. Sci., 1(2): 181-189.

Karuppasamy, P. K., Balachandran, K., Simmy George, Balu, S., Vimala Persis and Menon, N. G. 2008. Food of some deep sea fishes collected from the eastern Arabian Sea. J. Mar. Biol. Ass. India, 50(2): 134-138.

Kurup, B. M. and Samuel, C. T. 1986. Observations on the food and feeding habits of the whip fin mojarra Gerres filamentosus Cuvier (Perciformes: Gerridae) of the Vembanad Lake. Bull. Dept. Mar. Sci. Univ. Cochin, 14: 89-98.

Modica, L., Cartes, J. E. and Carrasson, M. 2014. Food consumption of five deep-sea fishes in the Balearic Basin (Western Mediterranean Sea): are there daily feeding rhythms in fishes living below $1000 \mathrm{~m}$ ? J. Fish Biol., 85: $800-820$

Natarajan, A. V. and Jhingran, A. G. 1961. Index of preponderance - A method of grading the food elements in the stomach analysis of fishes. Ind. J. Fish., 8(1): 54-59.

Nieland, H. 1980. Experiments on whether schooling by their prey affects the hunting behaviour of cephalopods and fish predators. J. Zool., 172(4): 549-569.

Qasim, S. Z. 1972. The dyanamics of food and feeding habits of some marine fishes. Indian. J. Fish., 19(1\&2): 11-28.

Pinkas, L., Oliphant, M. S. and Iverson, I. L. K. 1971. Food habits of albacore, bluefin tuna and bonito in Californian waters. Calif. Fish. Game, Fishery Bull., 152: 1-105.

R Core Team 2016. R: A language and environment for statistical computing. R Foundation for Statistical Computing, Vienna, Austria. https://www.R-project.org/.

Steven R. Chipps and James E. Garvey 2006. Assessment of food habits and feeding patterns. American Fisheries Society, 43 pp.

Smith, M. M. and Heemstra, P. C. 1986. Smith's sea fishes. Springer -Verlag, Berlin Heidelberg, London, 1047 pp.

Vander Zanden, M., Shuter, B., Lester, N. P. and Rasmussen, B. 2000. Within-and among-population variation in the trophic position of a pelagic predator, lake trout (Salvelinus namaycush). Can J. Fish. Aquat. Sci., 57: 725-731.

Venu, S. and Kurup, B. M. 2006. Distribution and biology of deepsea fishes Neoepinnula orientalis (Gilchrist and von Bonde 1924) and Psenes squamiceps (Lloyd, 1909) from west coast of Indian EEZ. J. Mar. Biol. Ass. India, 48(1): 24-28. 